УДК 665.63

\author{
П.І. ТОПІЛЬНИЦЬКИЙ, В.В. ТКАЧУК, О.Ю. РЕЧУН
}

НУ «Львівська політехніка»,

Луиьький національний технічний університет,

\title{
ВПЛИВ ВМІСТУ ХЛОРОРГАНІЧНИХ СПОЛУК В НАФТІ НА КОРОЗІЮ НАФТОТРАНСПОРТНОГО ОБЛАДНАННЯ
}

\author{
P.I. TOPILNTYSKYY, V.V. TKACHUK, O.YU. RECHUN \\ Lviv Polytechchnic National University, \\ Lutsk National Technical University
}

\section{INFLUENCE OF ORGANIC CHLORIN COMPOUNDS IN OIL ON CORROSION OF OIL TRANSPORT EQUIPMENT}

\section{https://doi.org/10.36910/6775-2310-5283-2022-15-25}

Мета. Оцінка впливу вмісту хлорорганічних сполук в нафті на корозію нафтотранспортного обладнання.

Результати. Хлорорганічні сполуки (ХОС) в додаток до неорганічних хлоридів $\epsilon$ джерелом хлористоводневої корозії обладнання транспортної системи. Їх наявність $у$ нафті є потениійно небезпечним для нафтопереробних підприємств, i виявляються вони лище в процесі очищення технологічного обладнання, трубопроводів і резервуарів. Тому не випадково вміст ХОС не нормується $і$ підлягає обов'язковому визначенню. На сьогодні нафтопереробні заводи не мають технологій, щз дозволяють нейтралізувати хлорорганічні сполуки або ж надійно захистити обладнання. Певний досвід по боротьбі з хлором на нафтопереробних заводах (НПЗ) уже отримано, але, на наму думку, жодна із запропонованих розробок поки не є достатньо ефективною.

Проведено дослідження корозійного впливу хлороформу, дихлорметану, метилену хлористого, трихлоретилену та перхлоретилену на металеві пластинки при концентрації ХОС в середовищі від 10 до 1000 ррт при температурі $20{ }^{\circ} \mathrm{C}$. Базовим середовищем для досліджень було товарне дизельне паливо з додаванням до нього певних ХОС або нафти з підвищеним вмістом ХОС. Металеві зразки - сталь Ст 20, метал з трубопроводу, резервуару, метал трубопроводу з чеської сталі. Серед досліджуваних ХОС виявлені найбільш корозійноактивні сполуки - дихлоретан, метилен хлористий та трихлоретилен. Металеві пластини з трубопроводу, резервуару, трубопроводу з чеської сталі проявляли стійкість до агресивного середовища на рівні «стійкий», а корозійна активність агресивного середовища оцінювалась як «середня».

Оиінюючи корозійний вплив хлорорганічних сполук в нафті на характер та швидкість корозії магістральних нафтопроводів, резервуарів та технологічного обладнання можна 
констатувати, щуо вміст ХОС в нафті в кількості до 500 ррт при температурі до $40{ }^{\circ} \mathrm{C}$ проявляє незначний корозійний вплив, а метал магістральних нафтопроводів, резервуарів та технологічного обладнання проявляе корозійну стійкість на рівні «стійкий» за шкалою оичінки корозійної стійкості металу відповідно до ГОСТ 9.502-82 (швидкість корозї може становити до 0,1 мм/рік).

Наукова новизна. Вперше встановлено корозійний вплив індивідуальних хлорорганічних речовин на матеріали нафтотранспортного обладнання.

Практична значимість. У результаті досліджень встановлено безпечну кількість хлорорганічних сполук в нафті, при якій корозія обладнання є мінімальною.

Ключові слова: нафтотранспортне обладнання, трубопроводи, хлорорганічні сполуки, корозія.

Постановка проблеми у загальному вигляді та ії зв'язок із важливими науковими чи практичними завданнями. Хлорорганічні сполуки (ХОС) в додаток до неорганічних хлоридів $є$ джерелом хлористоводневої корозії обладнання транспортної системи. Їх наявність у нафті $\epsilon$ потенційно небезпечним для нафтопереробних підприємств, і виявляються вони лише в процесі очищення технологічного обладнання, трубопроводів i резервуарів. Тому не випадково вміст ХOC не нормується і підлягає обов'язковому визначенню. На сьогодні нафтопереробні заводи не мають технологій, що дозволяють нейтралізувати хлорорганічні сполуки або ж надійно захистити обладнання. Певний досвід по боротьбі з хлором на нафтопереробних заводах (НП3) уже отримано, але, на нашу думку, жодна із запропонованих розробок поки не є достатньо ефективною [1-9].

Контроль вмісту неорганічних хлористих солей в нафті здійснюється за методом, суть якого полягає в екстракції хлоридів металів (в основному хлоридів натрію, кальцію і магнію, які розчиняються у воді) 3 подальшим титруванням водної витяжки. Більш складним завданням $є$ методичне забезпечення визначення вмісту ХОС в нафті. Вирішення цього завдання має свою специфіку: по-перше, нафта $\epsilon$ складною сумішшю вуглеводнів 3 мікровмістом ХОС, що вимірюється у мільйонних частках (ppm); по-друге, нафта містить сіркоорганічні сполуки, які заважають визначенню хлору.

Аналіз останніх досліджень, у яких започатковано вирішення проблеми. Проблемам корозії нафтопереробного обладнання присвячені праці А.М. Сухотіна [10], І.Л. Розенфельда [11], Ф.М. Хуторянського [12], В.В. Романчук [13-14].

Метою даною статті є проведення оцінки впливу хлорорганічних сполук у нафті на корозію нафтотранспортного обладнання. 
Об'єкти дослідження. Як середовище для проведення корозійних досліджень використано товарне дизельне паливо, показники якого відповідали вимогам ДСТУ 7688:2015.

Металеві пластини - сталь Ст 20, метал з трубопроводу, резервуару, 3 трубопроводу з чеської сталі.

Нафти, які були використані для досліджень (російська експортна суміш 1), були проаналізовані і містили:

- проба 1 - вміст ХОС 0,8 ppm;

- проба 2 - вміст ХОС 170 ppm;

- проба 3 - вміст ХОС 430 ppm;

- проба 4 - вміст ХОС 438 ppm.

Для подальших досліджень взято пробу 4, яка містила найбільшу кількість хлорорганічних сполук.

Методика проведення досліджень. Методика визначення впливу корозійноактивних хлорорганічних сполук у нафті на корозію нафтотранспортного обладнання полягала у визначенні втрати маси металевих зразків в середовищах 3 підвищеним вмістом ХОС та без них згідно з СОУ 11.1-00135390-034:2006. Температуру процесу регулювали та підтримували в заданих межах нагрівальним елементом магнітної мішалки та контактним термометром. Інтенсивність перемішування регулювали зміною швидкості обертання магнітної мішалки.

Оцінку корозійної стійкості металу та корозійної активності системи оцінювали за швидкістю корозії (табл. 1).

Таблиця 1. Шкала оцінки корозійної стійкості металу та корозійної активності системи (залізо та чорні метали)

\begin{tabular}{|c|c|c|c|}
\hline $\begin{array}{c}\text { Швидкість корозії } \\
\text { мм/рік }\end{array}$ & $\begin{array}{c}\text { Швидкість корозії, } \\
\text { г/м год }\end{array}$ & $\begin{array}{c}\text { Корозійна стійкість } \\
\text { метала }\end{array}$ & $\begin{array}{c}\text { Корозійна активність } \\
\text { системи }\end{array}$ \\
\hline До 0,001 & До 0,0009 & Повністю стійкий & Неактивна \\
\hline $0,001-0,005$ & $0,0009-0,0045$ & \multirow{2}{*}{ Підвищена стійкість } & \multirow{2}{*}{ Низька } \\
\hline $0,005-0,010$ & $0,0045-0,0090$ & & \\
\hline $0,01-0,05$ & $0,009-0,045$ & \multirow{2}{*}{ Стійкий } & \multirow{2}{*}{ Середня } \\
\hline $0,05-0,1$ & $0,045-0,09$ & & \\
\hline $0,10-0,5$ & $0,09-0,45$ & \multirow{2}{*}{ Знижена стійкість } & \multirow{2}{*}{ Підвищена } \\
\hline $0,5-1,0$ & $0,45-0,90$ & & \\
\hline $1,0-5,0$ & $0,9-4,50$ & \multirow{2}{*}{ Слабостійкий } & \multirow{2}{*}{ Висока } \\
\hline $5,0-10$ & $4,5-9,0$ & & \\
\hline$>10$ & $>9,0$ & Не стійкий & Дуже висока \\
\hline
\end{tabular}


Виклад основного матеріалу дослідження 3 повним обгрунтуванням отриманих наукових результатів. За даними нафтових компаній, основна частка хлорорганіки, яка виявлена в нафтах, приходиться на дихлоретан, дихлорметан, хлороформ, трихлоретилен, перхлоретилен, причому із зазначених продуктів вміст трихлоретилена найбільший. Ці хлорвмісні продукти подаються в нафту для розчинення парафінових відкладень та зменшення їх кількості у трубопроводах. Тому саме ці ХОС використовували для досліджень. Результати визначення впливу хімічного складу та концентрації ХОС на корозію нафтотранспортного обладнання наведено в таблицях 2-6.

Таблиця 2. Визначення корозійного впливу хлороформу на пластинку із сталі $20 \mathrm{~T}=30^{\circ} \mathrm{C}, \tau=2$ год.

\begin{tabular}{|c|c|c|c|c|c|c|c|}
\hline № & $\begin{array}{c}\text { К-ть } \\
\text { доданого } \\
\text { ХОС ,ppm }\end{array}$ & $\mathrm{G}_{1}$ & $\mathrm{G}_{2}$ & $\Delta \mathrm{G}$ & $\mathrm{V}_{\text {корозії }}$ & $\begin{array}{c}\text { Корозійна } \\
\text { стійкість } \\
\text { метала }\end{array}$ & $\begin{array}{c}\text { Корозійна } \\
\text { активність } \\
\text { системи }\end{array}$ \\
\hline 1 & 10 & 21,48001 & 21,48001 & 0 & 0 & $\begin{array}{c}\text { Підвищена } \\
\text { стійкість }\end{array}$ & Неактивна \\
\hline 2 & 50 & 21,48523 & 21,48523 & 0 & 0 & $\begin{array}{c}\text { Підвищена } \\
\text { стійкість }\end{array}$ & Неактивна \\
\hline 3 & 100 & 21,49175 & 21,49175 & 0 & 0 & $\begin{array}{c}\text { Підвищена } \\
\text { стійкість }\end{array}$ & Неактивна \\
\hline 4 & 200 & 21,28009 & 21,28009 & 0 & 0 & $\begin{array}{c}\text { Підвищена } \\
\text { стійкість }\end{array}$ & Неактивна \\
\hline 5 & 500 & 21,53010 & 21,53009 & 0,0001 & 0,0153 & Стійкий & Середня \\
\hline 6 & 1000 & 21,28100 & 21,28055 & 0,0004 & 0,0614 & Стійкий & Середня \\
\hline
\end{tabular}

Таблиця 3. Визначення корозійного впливу дихлоретану на пластинку із сталі $20 \mathrm{~T}=30^{\circ} \mathrm{C}, \tau=2$ год.

\begin{tabular}{|c|c|c|c|c|c|c|c|}
\hline № & $\begin{array}{c}\text { К-ть } \\
\text { доданого } \\
\text { ХОС ,ppm }\end{array}$ & $\mathrm{G}_{1}$ & $\mathrm{G}_{2}$ & $\Delta \mathrm{G}$ & $\mathrm{V}_{\text {корозії }}$ & $\begin{array}{c}\text { Корозійна } \\
\text { стійкість } \\
\text { метала }\end{array}$ & $\begin{array}{c}\text { Корозійна } \\
\text { активність } \\
\text { системи }\end{array}$ \\
\hline 1 & 10 & 21,25551 & 21,25551 & 0 & 0 & $\begin{array}{c}\text { Підвищена } \\
\text { стійкість }\end{array}$ & Неактивна \\
\hline 2 & 50 & 21,25623 & 21,25623 & 0 & 0 & $\begin{array}{c}\text { Підвищена } \\
\text { стійкість }\end{array}$ & Неактивна \\
\hline 3 & 100 & 21,25815 & 21,25815 & 0 & 0 & $\begin{array}{c}\text { Підвищена } \\
\text { стійкість }\end{array}$ & Неактивна \\
\hline 4 & 200 & 21,28412 & 21,28412 & 0 & 0 & $\begin{array}{c}\text { Підвищена } \\
\text { стійкість }\end{array}$ & Неактивна \\
\hline 5 & 500 & 21,29740 & 21,29710 & 0,0003 & 0,0460 & Стійкий & Середня \\
\hline 6 & 1000 & 21,27680 & 21,27605 & 0,0007 & 0,1075 & $\begin{array}{c}\text { Знижена } \\
\text { стійкість }\end{array}$ & Підвищена \\
\hline
\end{tabular}


Товарознавчий вісник. - 2022. - Випуск 15.

Таблиця 4. Визначення корозійного впливу метилену хлористого на пластинку із сталі $20 \mathrm{~T}=30^{\circ} \mathrm{C}, \tau=2$ год.

\begin{tabular}{|c|c|c|c|c|c|c|c|}
\hline$№$ & $\begin{array}{c}\text { К-ть } \\
\text { доданого } \\
\text { ХОС ,ppm }\end{array}$ & $\mathrm{G}_{1}$ & $\mathrm{G}_{2}$ & $\Delta \mathrm{G}$ & $\mathrm{V}_{\text {корозії }} / \mathrm{M}^{2}$ & $\begin{array}{c}\text { Корозійна } \\
\text { стійкість } \\
\text { металу }\end{array}$ & $\begin{array}{c}\text { Корозійна } \\
\text { активність } \\
\text { системи }\end{array}$ \\
\hline 1 & 10 & 21,26751 & 21,26751 & 0 & 0 & $\begin{array}{c}\text { Підвищена } \\
\text { стійкість }\end{array}$ & Неактивна \\
\hline 2 & 50 & 21,27302 & 21,27302 & 0 & 0 & $\begin{array}{c}\text { Підвищена } \\
\text { стійкість }\end{array}$ & Неактивна \\
\hline 3 & 100 & 21,49220 & 21,49210 & 0,0001 & 0,0153 & Стійкий & Середня \\
\hline 4 & 200 & 21,50120 & 21,50100 & 0,0002 & 0,0307 & Стійкий & Середня \\
\hline 5 & 500 & 21,28470 & 21,28430 & 0,0004 & 0,0460 & Стійкий & Середня \\
\hline 6 & 1000 & 21,49830 & 21,49765 & 0,0006 & 0,0921 & $\begin{array}{c}\text { Знижена } \\
\text { стійкість }\end{array}$ & Підвищена \\
\hline
\end{tabular}

Таблиця 5. Визначення корозійного впливу трихлоретилену на пластинку із сталі $20 \mathrm{~T}=30^{\circ} \mathrm{C}, \tau=2$ год.

\begin{tabular}{|c|c|c|c|c|c|c|c|}
\hline № & $\begin{array}{c}\text { К-ть } \\
\text { доданого } \\
\text { ХОС ,ppm }\end{array}$ & $\mathrm{G}_{1}$ & $\mathrm{G}_{2}$ & $\Delta \mathrm{G}$ & $\begin{array}{c}\mathrm{V}_{\text {корозії }} \\
\text { г/м² год }\end{array}$ & $\begin{array}{c}\text { Корозійна } \\
\text { стійкість } \\
\text { металу }\end{array}$ & $\begin{array}{c}\text { Корозійна } \\
\text { активність } \\
\text { системи }\end{array}$ \\
\hline 1 & 10 & 21,232510 & 21,232510 & 0 & 0 & $\begin{array}{c}\text { Підвищена } \\
\text { стійкість }\end{array}$ & Неактивна \\
\hline 2 & 50 & 21,241301 & 21,241301 & 0 & 0 & $\begin{array}{c}\text { Підвищена } \\
\text { стійкість }\end{array}$ & Неактивна \\
\hline 3 & 100 & 21,25855 & 21,25825 & 0,0003 & 0,0460 & Стійкий & Середня \\
\hline 4 & 200 & 21,26550 & 21,26510 & 0,0004 & 0,0613 & Стійкий & Середня \\
\hline 5 & 500 & 21,52220 & 21,52165 & 0,0005 & 0,0767 & Стійкий & Середня \\
\hline 6 & 1000 & 21,26510 & 21,26430 & 0,0008 & 0,1227 & $\begin{array}{c}\text { Знижена } \\
\text { стійкість }\end{array}$ & Підвищена \\
\hline
\end{tabular}

Таблиця 6. Визначення корозійного впливу перхлоретилену на пластинку із сталі $20 \mathrm{~T}=30^{\circ} \mathrm{C}, \tau=2$ год.

\begin{tabular}{|c|c|c|c|c|c|c|c|}
\hline № & $\begin{array}{c}\text { К-ть } \\
\text { доданого } \\
\text { ХОС ,ppm }\end{array}$ & $\mathrm{G}_{1}$ & $\mathrm{G}_{2}$ & $\Delta \mathrm{G}$ & $\begin{array}{c}\mathrm{V}_{\text {корозії }} \\
\text { г/м² год }\end{array}$ & $\begin{array}{c}\text { Корозійна } \\
\text { стійкість } \\
\text { металу }\end{array}$ & $\begin{array}{c}\text { Корозійна } \\
\text { активність } \\
\text { системи }\end{array}$ \\
\hline 1 & 10 & 21,50736 & 21,50736 & 0 & 0 & Підвищена & Неактивна \\
\hline 2 & 50 & 21,30985 & 21,30985 & 0 & 0 & Підвищена & Неактивна \\
\hline 3 & 100 & 21,51407 & 21,51387 & 0,0001 & 0,0153 & Стійкий & Середня \\
\hline 4 & 200 & 21,30124 & 21,30104 & 0,0002 & 0,0307 & Стійкий & Середня \\
\hline 5 & 500 & 21,51600 & 21,51570 & 0,0003 & 0,0460 & Стійкий & Середня \\
\hline 6 & 1000 & 21,51205 & 21,51155 & 0,0005 & 0,0767 & Стійкий & Середня \\
\hline
\end{tabular}


В результаті проведених досліджень встановлено, що найбільшу корозію викликали дихлоретан, метилен хлористий та трихлоретилен. Для проведення дослідження найбільш корозійноактивні сполуки - дихлоретан, метилен хлористий та трихлоретилен - були змішані в пропорції 1:1:1.

Матеріалом для досліджень були металеві пластини 3 трубопроводу, резервуару, трубопроводу з чеської сталі. Температура досліджень $-30{ }^{\circ} \mathrm{C}$ та $40{ }^{\circ} \mathrm{C}$. Час експозиції - 2 год.

Для повноти відтворюваності результатів було проведено 2 контрольні досліди в середовищі товарного дизельного палива (контрольний дослід № 1 та контрольний дослід № 2). Потім до кожного з контрольних дослідів додавали суміш ХОС (дослід № 1 та дослід № 2). Результати представлено в таблицях 7 -12 .

\section{Таблиця 7. Визначення корозійної дії суміші ХOC на метал трубопроводу} при $30{ }^{\circ} \mathrm{C}$

\begin{tabular}{|l|c|c|c|c|c|c|c|}
\hline $\begin{array}{l}\text { Найменування } \\
\text { досліду }\end{array}$ & $\begin{array}{c}\text { К-ть } \\
\text { доданого } \\
\text { ХОС ,ppm }\end{array}$ & $\mathrm{G}_{1, \Gamma}$ & $\mathrm{G}_{2, \Gamma}$ & $\Delta \mathrm{G}, \Gamma$ & $\begin{array}{c}\mathrm{V}_{\text {корозії }} \\
\text { г/м² год }\end{array}$ & $\begin{array}{c}\text { Корозійна } \\
\text { стійкість } \\
\text { метала }\end{array}$ & $\begin{array}{c}\text { Корозійна } \\
\text { активність } \\
\text { системи }\end{array}$ \\
\hline $\begin{array}{l}\text { Контрольний } \\
\text { дослід №1 }\end{array}$ & - & 44,30940 & 44,30940 & 0 & 0 & $\begin{array}{c}\text { Підвищена } \\
\text { стійкість }\end{array}$ & Неактивна \\
\hline Дослід №1 & 500 & 44,30735 & 44,30735 & 0 & 0 & $\begin{array}{c}\text { Підвищена } \\
\text { стійкість }\end{array}$ & Неактивна \\
\hline $\begin{array}{l}\text { Контрольний } \\
\text { дослід № 2 }\end{array}$ & - & 47,75540 & 47,75510 & 0 & 0 & $\begin{array}{c}\text { Підвищена } \\
\text { стійкість }\end{array}$ & Неактивна \\
\hline Дослід № 2 & 500 & 47,75220 & 47,75220 & 0 & 0 & $\begin{array}{c}\text { Підвищена } \\
\text { стійкість }\end{array}$ & Неактивна \\
\hline
\end{tabular}

Таблиця 8. Визначення корозійної дії суміші ХОС на метал трубопроводу при $40{ }^{\circ} \mathrm{C}$

\begin{tabular}{|l|c|c|c|c|c|c|c|}
\hline $\begin{array}{l}\text { Найменування } \\
\text { досліду }\end{array}$ & $\begin{array}{c}\text { К-ть } \\
\text { доданого } \\
\text { ХОС ,ppm }\end{array}$ & $\mathrm{G}_{1, \Gamma}$ & $\mathrm{G}_{2, \Gamma}$ & $\Delta \mathrm{G}, \Gamma$ & $\begin{array}{c}\mathrm{V}_{\text {корозії, }} \\
\text { г/м² год }\end{array}$ & $\begin{array}{c}\text { Корозійна } \\
\text { стійкість } \\
\text { метала }\end{array}$ & $\begin{array}{c}\text { Корозійна } \\
\text { активність } \\
\text { системи }\end{array}$ \\
\hline $\begin{array}{l}\text { Контрольний } \\
\text { дослід № 1 }\end{array}$ & - & 44,30735 & 44,30735 & 0 & 0 & $\begin{array}{c}\text { Підвищена } \\
\text { стійкість }\end{array}$ & Неактивна \\
\hline Дослід № 1 & 500 & 44,30626 & 44,30621 & 0,0005 & 0,0540 & Стійкий & Середня \\
\hline $\begin{array}{l}\text { Контрольний } \\
\text { дослід № 2 }\end{array}$ & - & 44,75180 & 44,75180 & 0 & 0 & $\begin{array}{c}\text { Підвищена } \\
\text { стійкість }\end{array}$ & Неактивна \\
\hline Дослід № 2 & 500 & 44,74980 & 44,74976 & 0,0004 & 0,0432 & Стійкий & Середня \\
\hline
\end{tabular}


Таблиця 9. Визначення корозійної дії суміші ХОС на метал резервуару при $30^{\circ} \mathrm{C}$

\begin{tabular}{|l|c|c|c|c|c|c|c|}
\hline $\begin{array}{l}\text { Найменування } \\
\text { досліду }\end{array}$ & $\begin{array}{c}\text { К-ть } \\
\text { доданого } \\
\text { ХОС ,ppm }\end{array}$ & $\mathrm{G}_{1, \Gamma}$ & $\mathrm{G}_{2, \Gamma}$ & $\Delta \mathrm{G}, \Gamma$ & $\begin{array}{c}\mathrm{V}_{\text {корозії, }} \\
\text { г/м² год }\end{array}$ & $\begin{array}{c}\text { Корозійна } \\
\text { стійкість } \\
\text { метала }\end{array}$ & $\begin{array}{c}\text { Корозійна } \\
\text { активність } \\
\text { системи }\end{array}$ \\
\hline $\begin{array}{l}\text { Контрольний } \\
\text { дослід №1 }\end{array}$ & - & 39,09210 & 39,09210 & 0 & 0 & $\begin{array}{c}\text { Підвищена } \\
\text { стійкість }\end{array}$ & Неактивна \\
\hline Дослід №1 & 500 & 37,93170 & 37,93165 & 0,0005 & 0,0609 & Стійкий & Середня \\
\hline $\begin{array}{l}\text { Контрольний } \\
\text { дослід № 2 }\end{array}$ & - & 37,95505 & 37,95505 & 0 & 0 & $\begin{array}{c}\text { Підвищена } \\
\text { стійкість }\end{array}$ & Неактивна \\
\hline Дослід № 2 & 500 & 37,94870 & 37,94565 & 0,0003 & 0,0368 & Стійкий & Середня \\
\hline
\end{tabular}

\section{Таблиця 10. Визначення корозійної дії суміші ХОС на метал резервуару при $40{ }^{\circ} \mathrm{C}$}

\begin{tabular}{|l|c|c|c|c|c|c|c|}
\hline $\begin{array}{l}\text { Найменування } \\
\text { досліду }\end{array}$ & $\begin{array}{c}\text { К-ть } \\
\text { доданого } \\
\text { ХОС ,ppm }\end{array}$ & $\mathrm{G}_{1, \Gamma}$ & $\mathrm{G}_{2, \Gamma}$ & $\Delta \mathrm{G}, \Gamma$ & $\begin{array}{c}\mathrm{V}_{\text {корозії, }} \\
\text { г/м год }\end{array}$ & $\begin{array}{c}\text { Корозійна } \\
\text { стійкість } \\
\text { метала }\end{array}$ & $\begin{array}{c}\text { Корозійна } \\
\text { активність } \\
\text { системи }\end{array}$ \\
\hline $\begin{array}{l}\text { Контрольний } \\
\text { дослід №1 }\end{array}$ & - & 37,92950 & 37,92950 & 0 & 0 & $\begin{array}{c}\text { Підвищена } \\
\text { стійкість }\end{array}$ & Неактивна \\
\hline Дослід №1 & 500 & 37,92754 & 37,92748 & 0,0006 & 0,0736 & Стійкий & Середня \\
\hline $\begin{array}{l}\text { Контрольний } \\
\text { дослід №2 }\end{array}$ & - & 37,94219 & 37,94219 & 0 & 0 & $\begin{array}{c}\text { Підвищена } \\
\text { стійкість }\end{array}$ & Неактивна \\
\hline Дослід №2 & 500 & 37,93996 & 37,93992 & 0,0004 & 0,0491 & Стійкий & Середня \\
\hline
\end{tabular}

Таблиця 11. Визначення корозійної дії суміші ХОС на метал трубопроводу 3 чеської сталі при $30{ }^{\circ} \mathrm{C}$

\begin{tabular}{|l|c|c|c|c|c|c|c|}
\hline $\begin{array}{l}\text { Найменування } \\
\text { досліду }\end{array}$ & $\begin{array}{c}\text { К-ть } \\
\text { доданого } \\
\text { ХОС ,ppm }\end{array}$ & $\mathrm{G}_{1, \Gamma}$ & $\mathrm{G}_{2, \Gamma}$ & $\Delta \mathrm{G}, \Gamma$ & $\begin{array}{c}\mathrm{V}_{\text {корозії, }} \\
\text { г/м² год }\end{array}$ & $\begin{array}{c}\text { Корозійна } \\
\text { стійкість } \\
\text { метала }\end{array}$ & $\begin{array}{c}\text { Корозійна } \\
\text { активність } \\
\text { системи }\end{array}$ \\
\hline $\begin{array}{l}\text { Контрольний } \\
\text { дослід №1 }\end{array}$ & - & 48,52175 & 48,52175 & 0 & 0 & $\begin{array}{c}\text { Підвищена } \\
\text { стійкість }\end{array}$ & Неактивна \\
\hline Дослід №1 & 500 & 48,51650 & 48,51610 & 0,0004 & 0,0483 & Стійкий & Середня \\
\hline $\begin{array}{l}\text { Контрольний } \\
\text { дослід №2 }\end{array}$ & - & 45,76205 & 45,76175 & 0,0003 & 0,0362 & Стійкий & Середня \\
\hline Дослід №2 & 500 & 45,75960 & 45,75910 & 0,0005 & 0,0603 & Стійкий & Середня \\
\hline
\end{tabular}


Таблиця 12. Визначення корозійної дії суміші ХОС на метал на метал трубопроводу з чеської сталі при $40^{\circ} \mathrm{C}$

\begin{tabular}{|l|c|c|c|c|c|c|c|}
\hline $\begin{array}{l}\text { Найменування } \\
\text { досліду }\end{array}$ & $\begin{array}{c}\text { К-ть } \\
\text { доданого } \\
\text { ХОС ,ppm }\end{array}$ & $\mathrm{G}_{1, \Gamma}$ & $\mathrm{G}_{2, \Gamma}$ & $\Delta \mathrm{G}, \Gamma$ & $\begin{array}{c}\mathrm{V}_{\text {корозії, }} \\
\text { г/м² год }\end{array}$ & $\begin{array}{c}\text { Корозійна } \\
\text { стійкість } \\
\text { метала }\end{array}$ & $\begin{array}{c}\text { Корозійна } \\
\text { активність } \\
\text { системи }\end{array}$ \\
\hline $\begin{array}{l}\text { Контрольний } \\
\text { дослід №1 }\end{array}$ & - & 48,51425 & 48,51425 & 0 & 0 & $\begin{array}{c}\text { Підвищена } \\
\text { стійкість }\end{array}$ & Неактивна \\
\hline Дослід №1 & 500 & 48,51224 & 48,51219 & 0,0005 & 0,0604 & Стійкий & Середня \\
\hline $\begin{array}{l}\text { Контрольний } \\
\text { дослід №2 }\end{array}$ & - & 45,75810 & 45,75810 & 0 & 0 & $\begin{array}{c}\text { Підвищена } \\
\text { стійкість }\end{array}$ & Неактивна \\
\hline Дослід №2 & 500 & 45,75615 & 45,75609 & 0,0006 & 0,0724 & Стійкий & Середня \\
\hline
\end{tabular}

Для досліджень була взята нафта (проба 4) з вмістом XОС 438 ppm, як така, що має проявляти найбільш активну корозійну дію на матеріал трубопроводів та зварних з'єднань. Ї̈̈ додавали до товарного дизельного палива в кількості $30 \%$.

Температура дослідження становила $30{ }^{\circ} \mathrm{C}$. Час експозиції - 2 год. Результати наведено в таблиці 13.

\section{Таблиця 13. Визначення корозійної дії суміші ХOC на метал на метал} трубопроводу з чеської сталі при $30^{\circ} \mathrm{C}$

\begin{tabular}{|l|c|c|c|c|c|c|}
\hline \multicolumn{1}{|c|}{ Пластина } & $\mathrm{G}_{1, \Gamma}$ & $\mathrm{G}_{2, \Gamma}$ & $\Delta \mathrm{G}, \Gamma$ & $\begin{array}{c}\mathrm{V}_{\text {корозії, }} \\
\text { г/м² год }\end{array}$ & $\begin{array}{c}\text { Корозійна } \\
\text { стійкість } \\
\text { метала }\end{array}$ & $\begin{array}{c}\text { Корозійна } \\
\text { активність } \\
\text { системи }\end{array}$ \\
\hline Резервуар & 39,06040 & 39,05965 & 0,0007 & 0,0853 & Стійкий & Середня \\
\hline $\begin{array}{l}\text { Трубопровід } 3 \\
\text { чеської сталі }\end{array}$ & 48,49250 & 48,49215 & 0,0003 & 0,0362 & Стійкий & Середня \\
\hline Трубопровід & 44,29320 & 44,29240 & 0,0008 & 0,0864 & Стійкий & Середня \\
\hline
\end{tabular}

Встановлено, що в одержаному корозійному середовищі швидкість корозії є незначною. Металеві пластини з трубопроводу, резервуару, трубопроводу 3 чеської сталі проявляли стійкість до агресивного середовища на рівні «стійкий», а корозійна активність агресивного середовища оцінювалась як «середня».

Висновки. Проведено дослідження корозійного впливу хлороформу, дихлорметану, метилену хлористого, трихлоретилену та перхлоретилену на металеві пластинки при концентрації ХОС в середовищі від 10 до 1000 ppm при температурі $20{ }^{\circ} \mathrm{C}$. Базовим середовищем для досліджень було товарне 
дизельне паливо з додаванням до нього певних ХОС або нафти з підвищеним вмістом ХОС. Металеві зразки - сталь Ст 20, метал з трубопроводу, резервуару, метал трубопроводу з чеської сталі. Серед досліджуваних ХОС виявлені найбільш корозійноактивні сполуки - дихлоретан, метилен хлористий та трихлоретилен.

Проведено визначення впливу хімічного складу та концентрації суміші ХОС на корозію сталі Ст 20. Дихлоретан, метилен хлористий та трихлоретилен були змішані в пропорції 1:1:1. Встановлено, що вміст цієї суміші ХОС в кількості в 10 до 500 ppm в дизельному паливі при 30-40 ${ }^{\circ} \mathrm{C}$ підвищує корозійну активність середовища максимум до рівня «середня», при цьому сталь Ст 20 проявляє корозійну стійкість на рівні «стійкий» за шкалою оцінки корозійної стійкості металу та корозійної активності системи відповідно до ГОСТ 9.502. При вмісті ХОС 1000 ppm у сталі Ст20 змінюється корозійна стійкість до рівня «знижена», а корозійна активність агресивного середовища оцінювалась як «підвищена».

Суміш найбільш корозійноактивних ХОС було додано до товарного дизельного палива в кількості 500 ppm i визначено корозійну дію на метал магістральних нафтопроводів, резервуарів та технологічного обладнання. Встановлено, що одержане корозійне середовище при $30{ }^{\circ} \mathrm{C}$ викликає незначну швидкість корозії, при цьому досліджувані металеві пластини з трубопроводу, резервуару та трубопроводу з чеської сталі проявляли стійкість до агресивного середовища на рівні «стійкий», а корозійна активність агресивного середовища оцінювалась як «середня».

Підвищення температури дослідів до $40^{\circ} \mathrm{C}$ незначно вплинуло на швидкість корозії під дією ХОС.

Визначено вплив нафти з найбільшим вмістом ХОС 438 ppm, яку вводили в дизельне паливо в кількості $30 \%$, на основний метал магістральних нафтопроводів. Металеві пластини з трубопроводу, резервуару, трубопроводу 3 чеської сталі проявляли стійкість до агресивного середовища на рівні «стійкий», а корозійна активність агресивного середовища оцінювалась як «середня».

В цілому, оцінюючи корозійний вплив ХОС на характер та швидкість корозії магістральних нафтопроводів, резервуарів та технологічного обладнання можна констатувати, що вміст ХОС в нафті в кількості до 500 ppm при температурі до $40{ }^{\circ} \mathrm{C}$ проявляє незначний корозійний вплив, а метал магістральних нафтопроводів, резервуарів та технологічного обладнання 
проявляє корозійну стійкість на рівні «стійкий» за шкалою оцінки корозійної стійкості металу відповідно до ГОСТ 9.502-82 (швидкість корозії може становити до $0,1 \mathrm{Mm} /$ рік).

\section{Список використаних джерел}

1. Хуторянский, Ф.М. Хлорорганические соединения в нефти. Мир нефтепродуктов. Вестник нефтяных компаний. 2002. № 3. С.6-7. 108

2. Хуторянский, Ф.М. ХОС. Распределение по фракциям и способы удаления из нефти на стадии ее подготовки к переработки. Мир нефтепродуктов. Bестник нефтяных компаний. 2002. №4. С.9-13.

3. Левченко, Д.Н. Необходимость удаления из нефти коррозионноагрессивных солей. Химия и технология топлив и масел. 1991. № 6. С. 43-44.

4. Варшавский, О.М. ХОС. Как решают проблему в ООО ПО «Киришинефтеоргсинтез». Мир нефтепродуктов. Вестник нефтяных компаний. 2003. № 2. С.16-18.

5. Азарова, С.Н. Скважины лечим - НПЗ калечим. Проблема “хлора" остается актуальной. Нефтегазовая вертикаль. 2002. № 8. С.14-16.

6. Uusitalo, M.A. Elevated temperature erosion-corrosion of thermal sprayed coatings in chlorine containing environments. Wear. 2002. № 252. P. 586-594

7. Хуторянский, Ф.М., Орлов Л.Н., Михалев А.Г., Уривская Г.М, Ергина Е.В., Крайнов Л.А., Цветков А.Л. Современные реагенты для химико-технологической защиты от коррозии конденсационно-холодильного оборудования установок первичной переработки нефти. Мир нефтепродуктов. Вестник нефтяных компаний. 2001. №1. С.13-19.

8. Позднышев, Г.Н. К проблеме снижения солянокислотной коррозии, солеотложения и содержания ХОС в продуктах переработки нефти на НПЗ. Интервал. 2002. №1. С.79-81.

9. Захарочкин, Л.Д., Вольфсон С.И., Клочкова Л.Г. Химико-технологические методы борьбы с низкотемпературной коррозией АВТ. Химия и технология топлив и масел. 1959. №3. C.46-52.

10. Коррозия и защита химической аппаратуры. Справочное руководство : [в $10 \mathrm{~T}] /$ под ред.Сухотин А. М. [и др. ]. М.: Химия, Т.9 : Нефтеперерабатывающая и нефтехимическая промышленность.1974. 576 с.

11. Розенфельд И. Л. Ингибиторы коррозии. М.: Химия, 1977. 352 с.

12. Хуторянский Ф.М. Комплексная программа химико-технологической защиты от коррозии конденсационно-холодильного оборудования атмосферных колонн установок первичной перегонки нефти. Разработка и внедрение. Доклад на научном семинаре «Актуальные проблемы нефтепереработки» в РГУ нефти и газа им. И.М. Губкина. Мир нефтепродуктов: Вестник нефтяных компаний. 2007. №1. С.45-48.

13. Романчук В.В. Антикорозійний захист нафтозаводського обладнання нітроген- та оксигенвмісними інгібіторами. Автореферат на здоб. наук. ступ. канд. тех. наук за спец. 05.17.07, НУ «Львівська політехніка». Львів. $2013.21 \mathrm{c.}$

14. V. Romanchuk, P. Topilnytsky Investigation of reagents with different chemical compositions for protection of oil primary refining equipment. Chemistry \& Chemical Technology Vol. 4 No 3. 2010. P. 231-236.

15. Моторні палива: властивості та якість. Підручник / С.В. Бойченко, А.П. Пушак, П.І. Топільницький, К.Лейда.- К.:Центр учбової літератури, 2017. 324 с. 
16. Топільницький П.І., Гринишин О.Б., Мачинський О.Я. Технологія первинної переробки нафти і газу: підручник. Львів: Видавництво Львівської політехніки, 2014. 468 с.

17. Пичугин В.Ф., Иванова Л.В. Буров Е.А. Улучшение триботехнических характеристик металлических пар в дизельном топливе при введении присадки. Химия и технология топлив и масел. № 4 (578), 2013. С.20-22.

\section{References}

1. Hutorianskiy F.M. Hlororganicheskiye soyedineniya v nefti. Mir nefteproduktov. Vestnik neftianyh kompaniy. 2002. №3. S.6-7 [in Russian].

2. Hutorianskiy F.M. Hlororganicheskiye soyedineniya. Raspriedeleniya po fraktsyiam I sposoby udaleniya iz nefti na stadiyi eyo podgotovki i pererabotki.. Mir nefteproduktov. Vestnik neftianyh kompaniy. 2002. № 4. S.9-13 [in Russian].

3. Levchenko D.N. Neobhodimost udaleniya iz nefti korozionnoagresivnyh solei. Himiya I tehnologiya topliv i masel. 1991. № 6. S. 43-44 [in Russian].

4. Varshavskyi, O.M. KhOS. Kak reshaiut problemu v OOO PO «Kyryshynefteorhsyntez». Myr nefteproduktov. Vestnyk neftianыkh kompanyi. 2003. № 2. S.16-18 [in Russian].

5. Azarova, S.N. Skvazhynы lechym - NPZ kalechym. Problema "khlora" ostaetsia aktualnoi. Neftehazovaia vertykal. 2002. № 8. S.14-16 [in Russian].

6. Uusitalo, M.A. Elevated temperature erosion-corrosion of thermal sprayed coatings in chlorine containing environments. Wear. 2002. №252. P. 586-594

7. Khutorianskyi, F.M., Orlov L.N., Mykhalev A.H., Uryvskaia H.M, Erhyna E.V., Krainov L.A., Tsvetkov A.L. Sovremennыe reahentы dlia khymyko-tekhnolohycheskoi zashchytы ot korrozyy kondensatsyonno-kholodylnoho oborudovanyia ustanovok pervychnoi pererabotky nefty. Myr nefteproduktov. Vestnyk neftianыkh kompanyi. 2001. №1. S.13-19 [in Russian].

8. Pozdnushev, H.N. K probleme snyzhenyia solianokyslotnoi korrozyy, soleotlozhenyia y soderzhanyia KhOS $\mathrm{v}$ produktakh pererabotky nefty na NPZ. Ynterval. 2002. №1. S.79-81 [in Russian].

9.Zakharochkyn, L.D., Volfson S.Y., Klochkova L.H. Khymyko-tekhnolohycheskye metodы borbы s nyzkotemperaturnoi korrozyei AVT. Khymyia y tekhnolohyia toplyv y masel. 1959. №3. S.46-52 [in Russian].

10.Korrozyia y zashchyta khymycheskoi apparaturd. Spravochnoe rukovodstvo : [v 10 t] / pod red.Sukhotyn A. M. [y dr. ]. M.: Khymyia, T.9 : Neftepererabatovaiushchaia y neftekhymycheskaia prombshlennost.1974. 576 s. [in Russian].

11. Rozenfeld Y. L. Ynhybytor korrozyy. M.: Khymyia, 1977. 352 s [in Russian].

12. Khutorianskyi F.M. Kompleksnaia prohramma khymyko-tekhnolohycheskoi zashchytы ot korrozyy kondensatsyonno-kholodylnoho oborudovanyia atmosfernыkh kolonn ustanovok pervychnoi perehonky nefty. Razrabotka y vnedrenye. Doklad na nauchnom semynare «Aktualnыe problemы neftepererabotky» v RHU nefty y haza ym. Y.M. Hubkyna. Myr nefteproduktov: Vestnyk neftianыkh kompanyi. 2007. №1. S.45-48 [in Russian].

13. Romanchuk V.V. Antykoroziinyi zakhyst naftozavodskoho obladnannia nitrohen- ta oksyhenvmisnymy inhibitoramy. Avtoreferat na zdob. nauk. stup. kand. tekh. nauk za spets. 05.17.07, NU «Lvivska politekhnika». Lviv. 2013.21 s. [in Ukrainian].

14. V. Romanchuk, P. Topilnytsky Investigation of reagents with different chemical compositions for protection of oil primary refining equipment. Chemistry \& Chemical Technology Vol. 4 No 3. 2010. P. 231-236 [in English].

15. Motorni palyva: vlastyvosti ta yakist. Pidruchnyk [Motor fuels: properties and quality. Textbook] / S.V. Bojchenko, A.P. Pushak, P.I. Topilnyczkyj, K. Lejda.- K.: Centr uchbovoyi literatury, 2017.- 324 s. [in Ukrainian]. 
16. Topilnyczkyj P.I., Grynyshyn O.B., Machynskyj O.Ya. Texnologiya pervynnoyi pererobky nafty i gazu: pidruchnyk [Primary oil and gas processing technology: a textbook].- L`viv: Vydavnycztvo Lvivskoyi politexniky, 2014. - 468 s. [in Ukrainian].

17. Pichugin V.F., Ivanova L.V. Burov E.A. Uluchshenije tribotexnicheskih harakterystik metallicheskih par $\mathrm{v}$ dizelnom toplive privvedenii prisadky [Improving tribological characteristics of metallic pairs in diesel fuel with the introduction of additives] // Himiya i texnologiya topliv $\mathrm{i}$ masel, - \# 4 (578), 2013.- S.20-22. [in Russian].

Goal. Estimation of influence of organochlorine impurities on corrosion of oil transportation equipment.

Results. The corrosion effect of chloroform, dichloromethane, methylene chloride, trichlorethylene and perchlorethylene on metal plates at the concentration of VOC in the environment from 10 to $1000 \mathrm{ppm}$ at a temperature of $20^{\circ} \mathrm{C}$ was studied. The basic environment for research was commercial diesel fuel with the addition of certain VOCs or oil with high VOC content. Metal samples - steel St 20, metal from the pipeline, tank, metal pipe from Czech steel. Among the studied VOCs, the most corrosive compounds were found-dichloroethane, methylene chloride and trichlorethylene.A mixture of the most corrosive VOCs was added to commercial diesel fuel in the amount of 500 ppm and the corrosive effect on the metal of main oil pipelines, tanks and process equipment was determined. It was found that the obtained corrosive environment at $30{ }^{\circ} \mathrm{C}$ causes a low corrosion rate, while the studied metal plates from the pipeline, tank and pipeline made of Czech steel showed resistance to aggressive environments at the level of "stable", and corrosive activity of aggressive environments was assessed as "medium".Increasing the temperature of the experiments to $40{ }^{\circ} \mathrm{C}$ had little effect on the corrosion rate under the action of VOCs.The effect of oil with a content of VOC 438 ppm, which was introduced into the diesel fuel in the amount of $30 \%$, on the base metal of the main oil pipelines was determined. Metal plates from the pipeline, tank, Czech steel pipeline showed resistance to the aggressive environment at the level of "stable", and the corrosion activity of the aggressive environment was assessed as "average".

Assessing the corrosive effect of organochlorine compounds on the nature and rate of corrosion of main oil pipelines, tanks and process equipment, it can be stated that the VOC content in oil up to $500 \mathrm{ppm}$ at temperatures up to $40^{\circ} \mathrm{C}$ has little corrosive effect, and the metal of main oil pipelines, tanks and process equipment exhibits corrosion resistance at the level of "stable" on the scale of assessment of corrosion resistance of the metal in accordance with GOST 9.502-82 (corrosion rate can be up to $0.1 \mathrm{~mm} /$ year).

Scientific novelty. At present, refineries do not have the technology to neutralize organochlorine compounds or reliably protect equipment. The same research is relevant. Some experience in the fight against chlorine refineries has already been obtained, but, in our opinion, none of the proposed developments is yet effective enough.

Practical importance. Organochlorine compounds are a source of hydrogen chloride corrosion of transport system equipment. Their presence in oil is potentially dangerous for refineries, and they are detected only in the process of cleaning process equipment, pipelines and tanks. Their neutralization is an important practical task in oil transportation.

Keywords: oil refining equipment, pipelines, organochlorine compounds, corrosion.

Стаття рекомендована до друку доктором технічних наук, професором Луиького НТУ Ягелюк С.В. Дата надходження в редакиію 01.12.2021 p. 